\title{
FEATURE Drought impact on crop production and the soil environment: 2012 experiences from lowa
}

Mahdi M. Al-Kaisi, Roger W. Elmore, Jose G. Guzman, H. Mark Hanna, Chad E. Hart, Matthew J. Helmers, Erin W. Hodgson, Andrew W. Lenssen, Antonio P. Mallarino, Alison E. Robertson, and John E. Sawyer

$\mathbf{E}$ normous challenges were presented by the 2012 drought. Poor water availability and high temperatures resulted in significant stress during critical phases of corn (Zea mays L.) and soybean (Glycine max L.) development. These stress factors lead to management challenges with insects, diseases, and reduced nutrient availability and uptake by plants. The drought triggered soil changes, particularly in conventional tillage systems, such as increased fracturing, crusting, and deterioration of soil structure and aggregation. All this reinforced the need for soil conservation planning, especially its necessary role in buffering against unpredictable conditions and the impacts of dry and wet events on production and soil quality. In 2011 the USDA's National Drought Mitigation Center reported that $43 \%$ of Iowa experienced moderate-drought conditions and nearly $10 \%$ experienced severe-drought conditions. In 2012, 100\% of Iowa experienced severe-drought conditions, while 65\% experienced extreme-drought conditions by October. This article addresses several effects of drought on soil and crop production and lessons learned that will help develop appropriate drought mitigation strategies for future soil and crop management practices.

The 2012 drought created unfavorable soil conditions for plant development and growth and changes in soil structure in many areas in the Midwest. These changes in soil structure included fracturing and cracking of the upper 15 to $30 \mathrm{~cm}(6$ to 15 in) of soil or deeper, depending on soil mineralogy and clay content (Al-Kaisi 2012). Continuous fracturing and crack-

Mahdi M. Al-Kaisi is professor, Roger W. Elmore is professor, Jose G. Guzman is research assistant, H. Mark Hanna is extension engineer, Chad E. Hart is associate professor, Matthew J. Helmers is associate professor, Erin W. Hodgson is assistant professor, Andrew W. Lenssen is associate professor, Antonio P. Mallarino is professor, Alison E. Robertson is associate professor, and John E. Sawyer is professor at the College of Agriculture and Life Sciences, lowa State University, Ames, lowa. ing to depths greater than 30 to $50 \mathrm{~cm}$ (15 to 20 in) occurred in soils with high content of expansible clays. Soil crusting became a problem as soil surfaces dried and hardened, especially under conventional tillage with poor crop-residue cover (Al-Kaisi and Hanna 2009). The lack of surface cover in winter of 2011 to 2012 caused deterioration of soil aggregates, allowing cementation to occur (Singer et al. 1992). These changes in soil structure can negatively impact soil-water-plant relationships, especially root system development, which reduces above-ground biomass and grain yields.

\section{DROUGHT EFFECTS ON GRAIN YIELD}

The forecast US corn yields for 2012 were 7.6 $\mathrm{Mg} \mathrm{ha}^{-1}$ (122 bu ac $\mathrm{bu}^{-1}$ ), or $24 \%$ below the trend line. The forecast Iowa corn yields for 2012 were $8.8 \mathrm{Mg} \mathrm{ha}^{-1}$ (140 bu $\mathrm{ac}^{-1}$ ) (USDA NASS 2012a), or 22\% below the long-term trend line (figure 1). This reduction compares to 1988 Iowa corn yields, which were 29\% below trend line. Yield variability across Iowa in 2012 was significantly affected by rain distribution and soil spatial variability in organic matter and texture.

In southeast Iowa, yields were extremely variable where differences in soil moisture holding capacity were apparent. Yield spatial variability was large, covering a wide range of soil textures and rainfall distribution. Surprisingly, there were corn yields over 12.5 $\mathrm{Mg} \mathrm{ha}^{-1}$ (200 bu ac ${ }^{-1}$ ); however, yield greatly depended on hybrid, soil type, and rainfall distribution and amount. The 2012 October corn yield forecast for southeast Iowa was $7.9 \mathrm{Mg} \mathrm{ha}^{-1}$ (126 bu $\mathrm{ac}^{-1}$ ) (USDA NASS 2012b), and the soybean yield forecast for this area was $2.8 \mathrm{Mg}$ $\mathrm{ha}^{-1}\left(42 \mathrm{bu} \mathrm{ac}^{-1}\right)$.

In central Iowa, corn yields ranged from 1.2 to $13.8 \mathrm{Mg} \mathrm{ha}^{-1}$ (20 to $220 \mathrm{bu} \mathrm{ac}^{-1}$ ). Harvest began about 4 weeks earlier than

\section{Figure 1}

The 30-year corn yield trends from 1982 to 2011 with October 2012 yield forecasts for lowa and the United States (USDA NASS 2012a, 2012C).

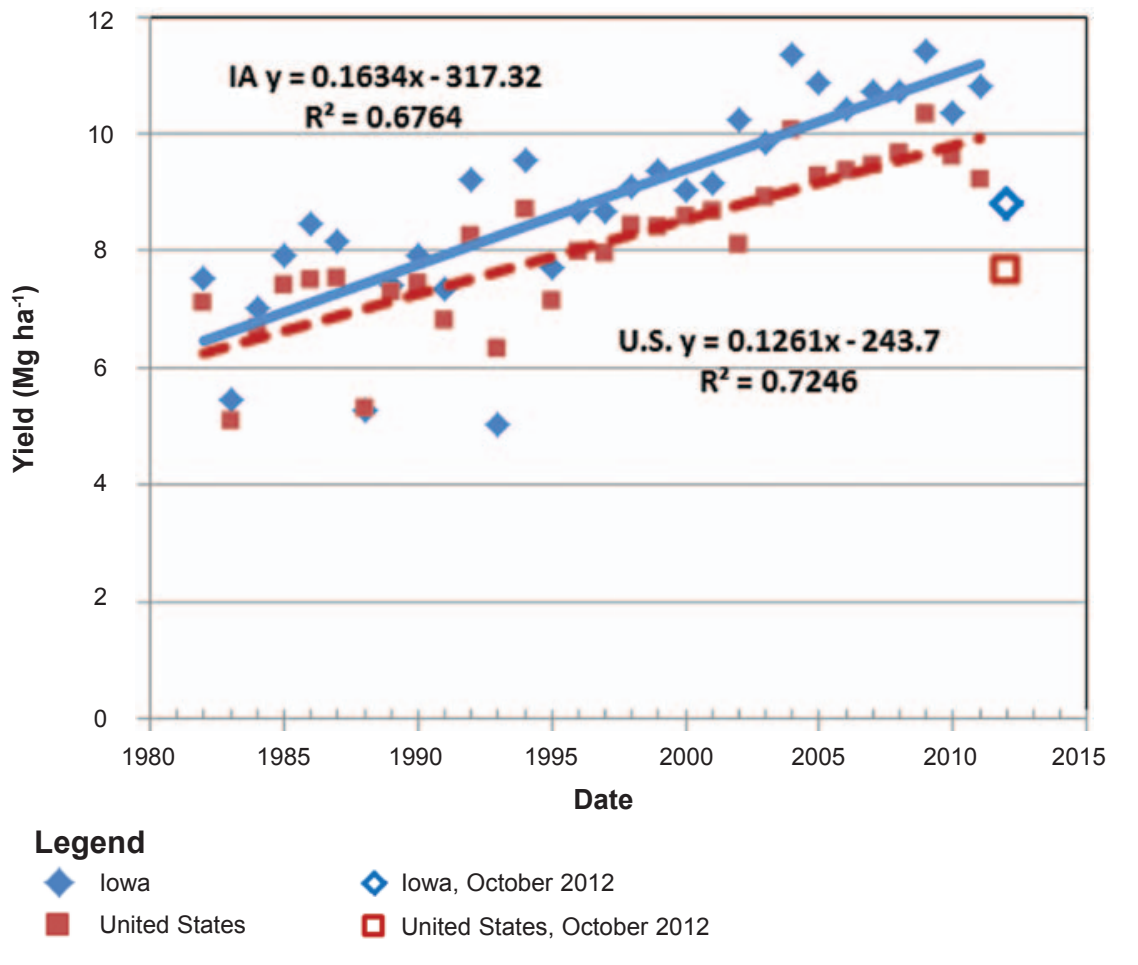


normal. Some fields damaged by strong winds in late July had crimped or broken corn stalks and yields of 1.2 to $3.1 \mathrm{Mg} \mathrm{ha}^{-1}$ (20 to $50 \mathrm{bu} \mathrm{ac}^{-1}$ ). Soils with medium soil texture outside of the Des Moines Lobe (central Iowa) had corn yield ranging from 6.2 to $8.7 \mathrm{Mg} \mathrm{ha}^{-1}$ (100 to $140 \mathrm{bu}$ $\left.\mathrm{ac}^{-1}\right)$. Meanwhile, fields in the Des Moines Lobe where soil is normally fine textured and poorly drained had corn yields ranging from 9.4 to $12.5 \mathrm{Mg} \mathrm{ha}^{-1}$ (150 to 200 bu $\left.\mathrm{ac}^{-1}\right)$. One of the factors contributing to poor crop development was the early onset of conventional tilling on some fields, especially where soil condition was too wet prior to planting in late April and early May. This resulted in uneven crop emergence. In addition, some corn planted into dry soil had uneven planting depth, as well as late and uneven crop emergence. Soybean yields ranged from 1.7 to $2.4 \mathrm{Mg}$ $\mathrm{ha}^{-1}$ ( 25 to $\left.35 \mathrm{bu} \mathrm{ac}^{-1}\right)$ in well-drained soils and from 2.7 to $3.4 \mathrm{Mg} \mathrm{ha}^{-1}$ (40 to $50 \mathrm{bu}$ $\left.\mathrm{ac}^{-1}\right)$ in fine-textured soils. Soils with high moisture-holding capacity and organic matter better tolerated drought conditions. Those soils helped mitigate corn yield loss, despite the significant lack of rain for the entire growing season. The 2012 October corn yield forecast for central Iowa was 9.5 $\mathrm{Mg} \mathrm{ha}^{-1}$ (151 bu ac${ }^{-1}$ ) (USDA NASS $2012 \mathrm{~b}$ ), and the soybean yield forecast for this area was $3.2 \mathrm{Mg} \mathrm{ha}^{-1}\left(48 \mathrm{bu} \mathrm{ac}^{-1}\right)$.

In western Iowa, corn yield ranged from almost 0 to $12.5 \mathrm{Mg} \mathrm{ha}^{-1}$ (0 to $200 \mathrm{bu} \mathrm{ac}^{-1}$ ). Soybean production experienced similar variability, ranging from 0.6 to $4.8 \mathrm{Mg} \mathrm{ha}^{-1}$ (10 to $\left.70 \mathrm{bu} \mathrm{ac}^{-1}\right)$. Soil types, water stress, and pest problems limited root growth, causing yield reduction in this region. In loess soils, corn yield reached over 12.5 $\mathrm{Mg} \mathrm{ha}^{-1}\left(200 \mathrm{bu} \mathrm{ac}^{-1}\right)$. No-till corn yields often exceeded $6.2 \mathrm{Mg} \mathrm{ha}^{-1}\left(100 \mathrm{bu} \mathrm{ac}^{-1}\right)$, in contrast with $2.5 \mathrm{Mg} \mathrm{ha}^{-1}\left(40 \mathrm{bu} \mathrm{ac}^{-1}\right.$ ) for conventional tillage yields in the same area. The 2012 October corn yield forecast for west central Iowa was $8.2 \mathrm{Mg} \mathrm{ha}^{-1}$ (130 bu ac ${ }^{-1}$ ) (USDA NASS 2012b), and the soybean yield forecast for this area was 2.7 $\mathrm{Mg} \mathrm{ha}^{-1}$ (39.5 $\left.\mathrm{bu} \mathrm{ac}^{-1}\right)$.

Drought effects were extremely variable in the northeast part of the state. Corn yields from fields with sandy-textured soils ranged from 0.9 to $4.0 \mathrm{Mg} \mathrm{ha}^{-1}$ (15 to $\left.65 \mathrm{bu} \mathrm{ac}^{-1}\right)$; yields on loam soils ranged from 8.7 to $11.3 \mathrm{Mg} \mathrm{ha}^{-1}$ (140 to $180 \mathrm{bu}$ $\left.\mathrm{ac}^{-1}\right)$. Soybean yields ranged from $0.2 \mathrm{Mg}$ $\mathrm{ha}^{-1}\left(30 \mathrm{bu} \mathrm{ac}^{-1}\right)$ on sandy soils to $3.4 \mathrm{Mg}$ $\mathrm{ha}^{-1}\left(50 \mathrm{bu} \mathrm{ac}^{-1}\right)$ on loam soils. The 2012 October corn yield forecast for northeast Iowa was $9 \mathrm{Mg} \mathrm{ha}^{-1}$ (144 bu ac${ }^{-1}$ ) (USDA NASS 2012b), and the soybean yield forecast for this area was $3.1 \mathrm{Mg} \mathrm{ha}^{-1}$ (46 bu $\left.\mathrm{ac}^{-1}\right)$. Under dry conditions, corn yields in continuous corn fields in southwest Iowa ranged from 5.6 to $8.1 \mathrm{Mg} \mathrm{ha}^{-1}$ (90 to $130 \mathrm{bu} \mathrm{ac}^{-1}$ ), while corn yields in fields with corn-soybean rotation ranged from 7.5 to11.3 $\mathrm{Mg} \mathrm{ha}^{-1}$ (120 to180 bu ac ${ }^{-1}$ ). Soybean yields ranged from 2.0 to $2.7 \mathrm{Mg}$ $\mathrm{ha}^{-1}$ (30 to $40 \mathrm{bu} \mathrm{ac}^{-1}$ ).

\section{DROUGHT EFFECTS ON PLANT DISEASES}

Drought affects dissemination of and infection by pathogens, disease development, and susceptibility of plants. In general, certain diseases are prevalent while others are less severe or do not occur. With drought conditions, we anticipated yield losses due to soybean cyst nematode ( $\mathrm{SCN}$ ) and charcoal rot, as well as aflatoxin contamination of corn grain as a consequence of Aspergillus ear rot.

\section{Figure 2}

An olive green powdery mold, characteristic of Aspergillus ear rot.



Symptoms and yield loss due to SCN may go unnoticed in years with adequate or excess rainfall, but in dry years, severe symptoms and significant yield loss are common. The impact of SCN on soybean yields in Iowa in 2012 is to be determined; however, we expect significant yield reductions. We observed increased SCN reproduction on SCN-resistant soybean varieties derived from a single breeding line, PI-88788, in field studies (Tylka 2012). Nevertheless, these varieties still yielded profitably, and resistance was not compromised. These studies were, however, done in years with average or above-average rainfall. Significant yield reductions due to increased SCN reproduction are likely in drought years.

Another disease that limits yield mostly during dry conditions is charcoal rot, caused by Macrophomina phaseolina. This is a stem disease of many field crops including corn and soybean. The Iowa State University Plant and Insect Diagnostic Clinic received several samples of soybean with symptoms and signs of charcoal rot during the 2012 growing season. All of the samples were from the western half of the state. No charcoal rot was reported on corn. 
The risk of Aspergillus ear rot (figure 2) and associated aflatoxin contamination of grain is very high during hot, dry conditions. Infection of corn by Aspergillus flavus, disease development, and aflatoxin production are favored by hot $\left(>30^{\circ} \mathrm{C}\right.$ $\left.\left[86^{\circ} \mathrm{F}\right]\right)$, dry conditions at pollination and during grain fill. Warm nights $\left(>21^{\circ} \mathrm{C}\right.$ $\left.\left[70^{\circ} \mathrm{F}\right]\right)$ may also increase risk of aflatoxin contamination (Hurburgh et al. 2012).

In 2012, corn pollination in Iowa occurred throughout much of July when high temperatures ranged from $31^{\circ} \mathrm{C}$ to $35^{\circ} \mathrm{C}\left(88^{\circ} \mathrm{F}\right.$ to $\left.95^{\circ} \mathrm{F}\right)$, with little or no precipitation. Night temperatures hovered around $21^{\circ} \mathrm{C}\left(70^{\circ} \mathrm{F}\right)$ during late grain fill (latter half of August). Thus, conditions were very favorable for infection and aflatoxin production. Nevertheless, a widespread outbreak of the ear rot and aflatoxin did not occur in Iowa. There were several reports of Aspergillus ear rot from scattered fields in western and eastern Iowa. Aflatoxin levels ranging from a few parts per billion (ppb) to over $370 \mathrm{ppb}$ were reported from elevators in this area (Charles Hurburgh, personal communication, September 2012).

\section{DROUGHT EFFECTS ON INSECTS}

The 2011 to 2012 winter was exceptionally warm with minimal snow cover throughout much of Iowa. Intuitively, some might think that higher temperatures might be beneficial for plant pests. Having a mild winter is favorable for some insects such as bean leaf beetle (Cerotoma trifurcata) because they are susceptible to subfreezing temperatures. However, most established species in Iowa are adapted to cold winters and actually require a cold resting period.

As noted in other sections, the soil moisture availability for most of Iowa was abnormally inadequate before planting in 2012. Therefore, we anticipated a droughtstressed growing season before planting even started. Some plant pests deteriorate in hot and dry weather commonly associated with drought conditions. Aphids in particular tend to dehydrate quickly and severely limit offspring production when temperatures are consistently above $32^{\circ} \mathrm{C}$ $\left(90^{\circ} \mathrm{F}\right)$. Other pests thrive in extreme temperatures and dry growing conditions.
Twospotted spider mite (Tetranychus urticae) is a good example of a pest associated with drought (Varenhorst et al. 2012).

All insects and mites mature to adults based on accumulating heat units Depending on the species, they have lower and upper developmental temperatures and have an optimal temperature range for producing offspring. With 2012 spring temperatures warmer than usual, most plant pests became active two to three weeks earlier. Examples of primary pests emerging early include Japanese beetle (Popillia japonica), western corn rootworm (Diabrotica virgifera virgifera), and bean leaf beetle. Having these pests infest seedlings can be very stressful to plants and is an early indicator of outbreak conditions later in the season.

Several plant pests affected Iowa corn and soybean in 2012. Notable examples that migrate to Iowa every year include black cutworm (Agrotis ipsilon) and potato leafhopper (Empoasca fabae). Migratory insects moved north to Iowa earlier than normal and populations were more abundant than in recent years. However, overwhelming, twospotted spider mites dominated the landscape. They are not consistent, economic pests in Iowa, so many farmers were unprepared to manage spider mites.

\section{DROUGHT EFFECTS ON NUTRIENT MANAGEMENT}

Nitrogen. Nitrogen $(\mathrm{N})$ applications were generally completed in the fall or spring, well before the extent of the drought was known. In drought situations, poor plant growth can result in nitrate accumulation in vegetative tissues, especially the lower corn stalk. Testing corn silage in 2012 was important to determine the safety for livestock feeding.

Needed corn $\mathrm{N}$ fertilization rates are lower in dry growing seasons. Therefore, if below-normal rainfall continues into 2013, reduced $\mathrm{N}$ rates could be applied for the 2013 crop. From the Maximum Return to $\mathrm{N}$ recommendations (Sawyer et al. 2006; ISU 2012), an $\mathrm{N}$ rate at the low end of the profitable range could be used. With drastic reductions in corn yield, $\mathrm{N}$ uptake would be low, and high carryover soil nitrate-N $\left(\mathrm{NO}_{3}-\mathrm{N}\right)$ could be accounted for as an adjustment to 2013 rates. Carryover $\mathrm{NO}_{3}-\mathrm{N}$ can be estimated by sampling the soil profile after harvest, or preferably in spring. If fall/early spring precipitation is well above normal, carryover $\mathrm{NO}_{3}-\mathrm{N}$ will be reduced, especially in soils with high leaching potential.

Phosphorus and Potassium. Earlyseason potassium $(\mathrm{K})$ deficiency symptoms occurred in many 2012 corn and soybean fields. This is common in dry soils and is a result of many factors, including reduced root growth and slow replenishment of plant-available soil $\mathrm{K}$ pools.

Drought reduces phosphorus $(\mathrm{P})$ and $\mathrm{K}$ removal with harvest, which increases availability of these nutrients for the next crop. Silage harvest typically increases $\mathrm{P}$ and $\mathrm{K}$ removal compared with grain harvest, but drought conditions can differentially affect plant dry matter production and nutrient accumulation. Removal can be estimated from average amounts per unit of yield (Sawyer et al. 2002) or from laboratory analysis of silage samples. With yield monitors, it is easy to determine variable yields and determine associated $\mathrm{P}$ and $\mathrm{K}$ removal. In extreme cases with no or very limited crop harvest, more $\mathrm{P}$ and $\mathrm{K}$ will be recycled from plant tissues than normal and be available for the next crop. Application needs for the 2013 crop could be directly adjusted for change in removal from expected or planned.

Soil Sampling and Testing. Dry conditions can impact post-harvest soil-test results with varying effect, depending on several factors: less removal of soil $\mathrm{P}$ and $\mathrm{K}$ with harvest, change in $\mathrm{P}$ and $\mathrm{K}$ recycling/leaching from plants or crop residue, slower equilibrium between soil nutrient pools, greater sampling error, and lower soil $\mathrm{pH}$ due to increased soluble salts. Waiting until after rainfall or sampling in the spring would improve soil test reliability.

\section{DROUGHT EFFECT ON WATER QUALITY}

The 2012 drought resulted in well below normal stream flow throughout river basins in the Midwest because of less rain and runoff and lower groundwater levels. As a result, sediment and nutrient loading in these rivers has been lower. However, these low stream flows could lead to adverse effects on stream water tempera- 
ture, dissolved oxygen, and eutrophication in streams. This concern was documented in an assessment of the Meuse river in Europe as a result of droughts in 1976 and 2003 (van Vliet and Zwolsman 2008). Low levels of dissolved oxygen and/or high stream water temperatures can have detrimental impacts on the aquatic community in streams.

A concern relative to water quality following the drought may be the $\mathrm{NO}_{3}-\mathrm{N}$ concentration and loading from agricultural landscapes. During the drought, soil $\mathrm{NO}_{3}-\mathrm{N}$ can accumulate within the soil profile and then be lost during subsequent periods of excess precipitation. An example of this was at two subsurface drainage water quality monitoring sites in Iowa following two relative dry years in 1988 and 1989. Weed and Kanwar (1996) monitored $\mathrm{NO}_{3}-\mathrm{N}$ export in subsurface drainage from 1990 to 1992 at Iowa State University's Northeast Research Farm near Nashua, Iowa, and documented flowweighted annual $\mathrm{NO}_{3}-\mathrm{N}$ concentrations as high as $64.65 \mathrm{mg} / \mathrm{L}$ from a continuous corn system in 1990. Nitrate-nitrogen concentrations from this same system were $11.95 \mathrm{mg} / \mathrm{L}$ in 1992. Lawlor et al. (2008) reported on $\mathrm{NO}_{3}-\mathrm{N}$ export from a field experimental site near Gilmore City, Iowa, from 1990 to 2004. For the period from 1990 to 1993, the highest $\mathrm{NO}_{3}-\mathrm{N}$ concentrations were observed in 1990 following a year (1989) when no subsurface drainage occurred at the site. To highlight this, $\mathrm{NO}_{3}-\mathrm{N}$ concentrations of $11.4 \mathrm{mg} / \mathrm{L}$ were observed from a cornsoybean system where no $\mathrm{N}$ was applied in 1989 and 1990. The $\mathrm{NO}_{3}-\mathrm{N}$ concentration from this system where no $\mathrm{N}$ was applied was reduced to $5.0 \mathrm{mg} / \mathrm{L}$ in 1993 following three years with above normal precipitation. Both these studies highlight that growing seasons with below-normal precipitation and no or little drainage can result in $\mathrm{N}$ storage and carryover within the soil profile that can be lost from the system during subsequent drainage events. To mitigate potential concerns following the drought, producers should consider residual $\mathrm{NO}_{3}$ within the soil profile when making management decisions relative to future $\mathrm{N}$ application rates.

\section{DROUGHT EFFECTS ON HARVEST AND TILLAGE EQUIPMENT}

Tillage Equipment. Dry topsoil increased mechanical penetration resistance and accelerated wear of knives, sweeps, and discs. Equipment operators were reminded to check operating depth and if too shallow were urged to transfer weight using down pressure springs or additional ballast.

General Harvest. Variability affected combine settings, at times during the same pass of the combine. Irregular corn included reduced ear diameter and few oversized kernels (pollination problem) on a single ear along with normal- sized ears and kernels. Stalk diameters varied from normal to small, with weak lower stalks that increased stalk lodging. Irregular soybeans included smaller or fewer soybeans or pods, variable stem height, and mature pods on green stems. Prescouting fields for crop conditions proved to be a useful but sometimes frustrating exercise.

Corn harvest was two to four weeks early with increased fire potential due to dry material and warmer temperatures. Combine operators were urged to spend time cleaning engine compartments, checking extinguishers, and preparing harvest crews for emergency action. Early evidence suggests fewer fires than expected. Fungus spores and dust required frequent cleaning of the secondary engine air filter and/or changing of the primary air filter.

Corn Harvest. Because of smaller ears, the gap between snapping plates above stalk rolls on corn heads was reduced to avoid kernel shelling on stalk rolls. Lodged stalks reduced travel speed and in some cases a header reel was added. If ears were uniformly smaller, narrower concave clearance improved threshing. Since corn was drier than normal at harvest, operators avoided excessive rotor speeds. Smaller kernels reduced cleaning shoe sieve opening sizes, but fan speed remained high as test weight was surprisingly unaffected in most areas.

Soybean Harvest. Almost 90\% of machine soybean losses occur at the head (Quick and Buchele 1974). Preharvest losses were greater where pods opened prematurely prior to harvest. Combine shatter loss increased with partially opened pods and green stems. Such con- ditions require sharp cutterbar knives in close register with guards (i.e., full knife stroke between guard points). Low or thin plant populations meant that operators needed to decrease concave settings slightly to improve feeding. Green stems required higher rotor speeds to maintain threshing. Because of smaller or lighter weight, soybeans operators reduced cleaning shoe sieve opening size and fan speed, respectively.

\section{ECONOMIC IMPACTS OF DROUGHT}

The 2012 drought has had and will continue to have a substantial impact on agricultural markets for at least the next 18 months. As the prospects for the corn and soybean crops diminished, the prices for those crops rose to record levels. However, as the harvest progressed, crop prices fell. Potential record prices still exist, but the records will not be quite as high. The US drought is globally significant as the United States is the top producer of corn and soybeans, producing roughly 35\% of the world's corn and soybeans. The United States is also a dominant partner in global trade for both crops. So, the US shortfall is also a world shortfall.

While crop losses have been significant, the larger economic impact will be on the livestock industry. The record high crop prices represent record high feed costs to the livestock industry. Alternative feeds are also in short supply due to the drought. With feed availability low and feed prices high, livestock returns are negative and the livestock sector is shrinking. Most of the international demand for corn and soybean meal is for livestock feed. Negative margins for domestic livestock feeders often correlate with negative margins and less feed demand from international livestock feeders. Corn exports are down nearly 40\% compared to last year. Soybean exports, though, have been stronger as international demand has held despite the high prices.

Another factor which has pushed prices higher than in the past is biofuel development. Ethanol has become the largest single source of demand for US corn. However, even the ethanol industry has felt this drought. The high corn prices shrank ethanol margins, lowering profitability 
enough for several plants to shut down. Overall ethanol production retreated 10\% this summer and has still not recovered.

However, in the end, demand remains strong enough to hold crop prices high. Before the drought, corn prices were in the US $\$ 5 \mathrm{bu}^{-1}$ range. Now, corn prices are holding in the US $\$ 7 \mathrm{bu}^{-1}$ range, a $40 \%$ increase. Soybean prices were around US $\$ 12 \mathrm{bu}^{-1}$, and now they are in the US $\$ 14$ range. That is just the short-term effect of the drought. Future prices for corn and soybeans indicate that it will take some time for supplies to rebound.

\section{MANAGING SOIL IN DRY CONDITIONS}

Soil management practices can improve soil water storage efficiency and subsequent availability for crop use, decreasing drought effects. These techniques vary with soil texture, structure, and organic matter content (Williams et al. 1983; Rawls et al. 2003). With exception of soil texture, appropriate management can improve soil quality by (1) improving soil aggregation, (2) increasing water storage efficiency by reducing evaporation, and (3) increasing water infiltration rate (figure 3). Midwest soils can be highly susceptible to water erosion, especially during early spring, prior to establishment of a new crop. During this time, residue left on the soil surface after harvest and growing vegetation are significant factors in minimizing soil erosion and for improving soil moisture content, an essential factor for decreasing drought effects later in the growing season. Essential soil management practices that can reduce the potential for drought-induced yield losses are as follows:

- Tillage Management: Tilling dry soils damages soil structure. When substantial rain occurs, tilled soils will have fewer stable aggregates, resulting in significantly more soil erosion and loss of residual nutrients. Tillage thus decreases subsoil moisture recharge necessary for high yields during normal precipitation cycles. No-tillage or minimum tillage practices can decrease the effects of extreme weather conditions such as drought.

- Residue Management: Crop residue cover plays a significant role in soil sustainability. Foremost, surface

\section{Figure 3}

Cumulative water infiltration with different tillage systems (NT= no-till, ST=strip-tillage, $\mathrm{CP}=$ chisel plow, $\mathrm{DR}=$ deep rip, and $\mathrm{MP}=$ Moldboard plow). Percentage above each bar represents increase or decrease compared to NT.

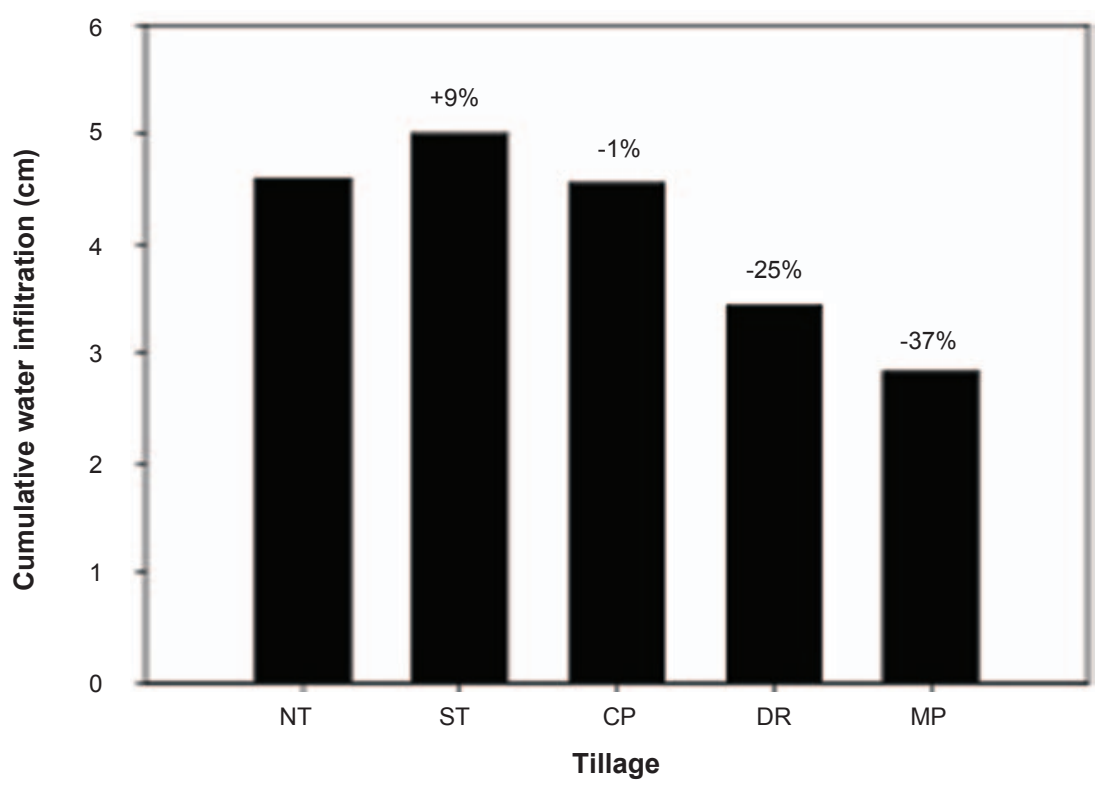

residue physically protects soil from potential erosion during heavy rain events. Residue increases opportunities for recharging soil profile, providing greater water availability later in the growing season. To achieve these benefits from surface residue, management starts during harvest by leaving at least $30 \mathrm{~cm}$ (12 in) of corn stubble standing above the surface. Upright residue traps store moisture effectively and slow downslope water movement.

- Cover Crops Management: Cover crops can play an important role by protecting soil from water erosion, improving soil structure, increasing organic matter, and significantly reducing nutrient losses. The early harvest in 2012 provided an opportunity to seed cover crops to protect soil from potential erosion from fall into spring 2013, utilize excess soil nitrate after harvest, and provide carbon input that will help improve soil quality. However, in dry conditions the main challenge is the establishment of the cover crop when soil moisture is limited.

\section{LESSONS OF 2012 DROUGHT}

The numerous lessons learned from the 2012 drought reinforce the value of conservation planning and its role in mitigating drought events and their impacts on crop production and soil quality:

- Crop residue retention with no-till systems improves water infiltration rate and conserves soil water content by reducing soil cracking and crusting and preserving soil structure.

- Corn following corn suffered greater yield losses than corn following soybean. Continuous corn typically does not yield as well as corn after soybean, but the yield differential was much greater in 2012.

- Cover crops can accumulate residual $\mathrm{NO}_{3}-\mathrm{N}$, thus decreasing losses from the root zone. Much of the $\mathrm{N}$ accrued in cover crops will become available to subsequent crops.

- The reduction of corn plant growth and grain fill during drought led to high $\mathrm{NO}_{3}$ accumulations in vegetative plant tissues, particularly in the lower corn stalk. Testing corn silage or baled stalks was important in 2012 to determine if $\mathrm{NO}_{3}-\mathrm{N}$ levels were safe for livestock.

- Corn $\mathrm{N}$ fertilization rates necessary to provide optimum yield typically are lower in years with below-normal rainfall. This effect can persist across 
multiple years of dry conditions, even with a return to normal rainfall. Therefore, effects of dry conditions should be considered in decisions for $\mathrm{N}$ application rates to 2013 corn crops.

- Corn silage harvest results in greater P and $\mathrm{K}$ removal than grain harvest alone since most of the aboveground plant is harvested. This increased removal rate from grain-only harvest should be considered in nutrient plans for subsequent crops.

- Dry fall conditions can impact soil test results. Predicting nutrient availability during drought is difficult. Sampling after fall rainfall occurs or sampling in the spring improves soil test reliability.

- Drought revealed that genetics may have a limited role in protecting yield without optimum moisture availability in the absence of an integrated crop management system. Significant rootworm feeding damage was observed in 2012 on hybrids with Bt rootworm resistance. Decreased root volume following root pruning results in lower water use under drought conditions, more crop stress, and reduced yields.

- The jury is still out on drought-tolerant hybrids. Unfortunately, results of scientifically valid comparisons of similar genetics with and without drought tolerance are not yet available.

- Planting a range of hybrid maturities will help spread risk, but plant only hybrids adapted to your area. Nonadapted hybrids may have neither the yield potential nor disease resistance of adapted hybrids.

\section{REFERENCES}

Al-Kaisi, M. 2012. Dry soil conditions and liquid manure application. Ames, IA: Iowa State University Extension and Outreach, Integrated Crop Management News.

Al-Kaisi, M., and M. Hanna. 2009. Residue management and cultural practices. Extension bulletin-PM1901a. Ames, IA: Iowa State University Extension.

Hurburgh, C., D. Loy, and A. Robertson. 2012. Aflatoxins in corn. PM 1800. Revised July 2012. Ames, IA: Iowa State University.

ISU (Iowa State University). 2012. Corn Nitrogen Rate Calculator. Ames, IA: Iowa State University,
Agronomy Extension. http://extension.agron. iastate.edu/soilfertility/nrate.aspx.

Lawlor, P.A., M.J. Helmers, J.L. Baker, S.W. Melvin, and D.W. Lemke. 2008. Nitrogen application rate effects on nitrate-nitrogen concentrations and losses in subsurface drainage. Transaction of the American Society of Agricultural and Biological Engineers 51(1): 83-94.

Quick, G.R., and W. F.Buchele. 1974. Reducing combine gathering losses in soybeans. Transactions of the American Society of Agricultural Engineers 17(6):1123-1129.

Rawls, W.J.,Y.A. Pachepsky, J.C. Ritchie, T.M. Sobecki, and H. Bloodworth. 2003. Effect of soil organic carbon on soil water retention. Geoderma 116:61-76.

Sawyer, J.E., A.P. Mallarino, R. Killorn, and S.K. Barnhart. 2002. A general guide for crop nutrient and limestone recommendations in Iowa. PM 1688. Ames, IA: Iowa State University Extension.

Sawyer, J., E. Nafziger, G. Randall, L. Bundy, G. Rehm, and B. Joern. 2006. Concepts and rationale for regional nitrogen rate guidelines for corn. Publ. PM 2015. Ames, IA: Iowa State University Extension.

Singer, M.J., R.J. Southard, D.N. Warrington, and P. Janitzky. 1992. Stability of synthetic sandclay aggregates after wetting and drying cycles. Soil Science Society of America Journal. 56:1843-1848.

Tylka, G.L. 2012. 2012 season is not a good one to "roll the dice" with SCN. Integrated Crop
Management News. Iowa State University Extension and Outreach. http://bit.ly/zOenx3.

USDA NASS (National Agricultural Statistics Service). 2012a. Iowa Ag News-Crop Production. October 11, 2012. http://www.nass.usda.gov/ Statistics_by_State/Iowa/Publications/Crop_ Report/reports/2012/octprod12.pdf.

USDA NASS. 2012b. Iowa Ag News-Crop Production District Forecasts. October 12, 2012. http://www.nass.usda.gov/Statistics_by_State/ Iowa/Publications/Crop_Report/reports/2012/ oct_district_estimate12.pdf.

USDA NASS. 2012c. Crop Production Annual Summary. http://usda.mannlib.cornell.edu/ MannUsda/viewDocumentInfo.do?document ID $=1047$.

Van Vliet, M.T.H., and J.J.G. Zwolsman. 2008. Impacts of summer droughts on the water quality of the Meuse river. Journal of Hydrology 353:1-17.

Varenhorst, A., M. O’Neal, and E. Hodgson. 2012. Early confirmation of twospotted spider mite. In Integrated Crop Management News, June 8, 2012. http://bit.ly/Kh9ylR.

Weed, D.A.J., and R.S. Kanwar. 1996. Nitrate and water present in and flowing from root-zone soil. Journal of Environmental Quality 25(4): 709-719.

Williams, J., R.E. Prebble, W.T. Williams, and C.T. Hignett. 1983. The influence of texture,structure and clay mineralogy on the soil moisture characteristic. Australian Journal of Soil Research 21:15-32. 